\title{
FACTORS AFFECTING THE ONLINE ECONOMY ON A REGIONAL BASIS
}

\author{
RoLAND SCHMUCK ${ }^{1}$ \\ University of Pécs (Hungary)
}

\begin{abstract}
The online economy takes a huge role in today's globalized world. Internet as a general purpose technology changes how companies operate, but it also changes the markets. The online economy has a huge effect on people's everyday life, private and public companies as well. The goal of this paper is to analyse the global online economy by countries of origin answering the question which countries dominate the internet. After deep literature survey on the subject the Alexa Top 500 database is used to analyse it by the most visited websites in the world. The analysis shows the online economy is dominated by the USA and China. Correlation analysis confirms that GDP correlates with websites originating from that country. This means highly developed countries have better online economy with more websites, dominating the online economy.

KEYWORDS: globalization, online, economy, website.
\end{abstract}

JEL CODES: L86, M21, 019

\section{Introduction}

The online economy is getting more and more important in the world economy. As this part of the economy is a new one, it has not received as much attention from researchers as the 'traditional' economy.

Problem. As companies can work from distant countries through the internet, it is not clear which are the dominating countries in the online economy. One may think that it is dominated by those countries which dominate the 'traditional' economy or it may be dominated by those countries which has the most population as people create content on the internet.

Purpose. Thepurpose of this paper is to describe and analyse the online economy in a globalised world, defining which countries are dominating it, giving a nationality outlook on the internet.

Object. The object of the research is to describe the importance of the internet as a general purpose industry and analyse the online economy on a nationality basis. The paper aims to discuss the current trends in the topic including discussing why internet is a general purpose technology, how it is connected with 'traditional' markets and how it affects them. The objectives of the current research are to answer which countries have the highest role in the only economy and try to find some correlation between this, the GDP and the population of the countries.

Tasks. The author first overviews the online economy, than takes a deeper research into the nationality of websites. The research methods are based on deep literature review of those articles and books that are considered relevant on the topic by mainstream economists. Two hypothesis are set and analysed. Own research is done by analysing the Alexa Top 500 database. Correlation analysis with the World Bank (2013) GDP and population data is done.

Roland Schmuck - University of Pécs, Faculty of Economics, Strategic Studies Department

E-mail: schmuck@ktk.pte.hu

Tel.: +36 $72501599 / 23265$ 
1. The beginnings of the online business

On 15 March 1985 the first registered domain name, symbolics.com was registered. Since that time, the Internet has revolutionized the business processes and even changed people's everyday lives. During this time, a number of innovative "dot-com" companies invented and used new business models. New products and services have been created, changing the purchasing habits of people and the distribution channels of companies. Internet has not only resulted in economic growth, but also changed social relations (Atkinson et al, 2010: 2) In December 2011 there were 2.2 billion internet users world-wide, which was $32.7 \%$ of the total population of the world (Internet World Stats, 2012). Internet usage spread at an amazing speed. Only 18 thousand websites existed in the world in 1995, but 80 million .com domain nameswere registered in 2010 with an average monthly increment of 668 thousand. (Atkinson et al, 2010: 1).

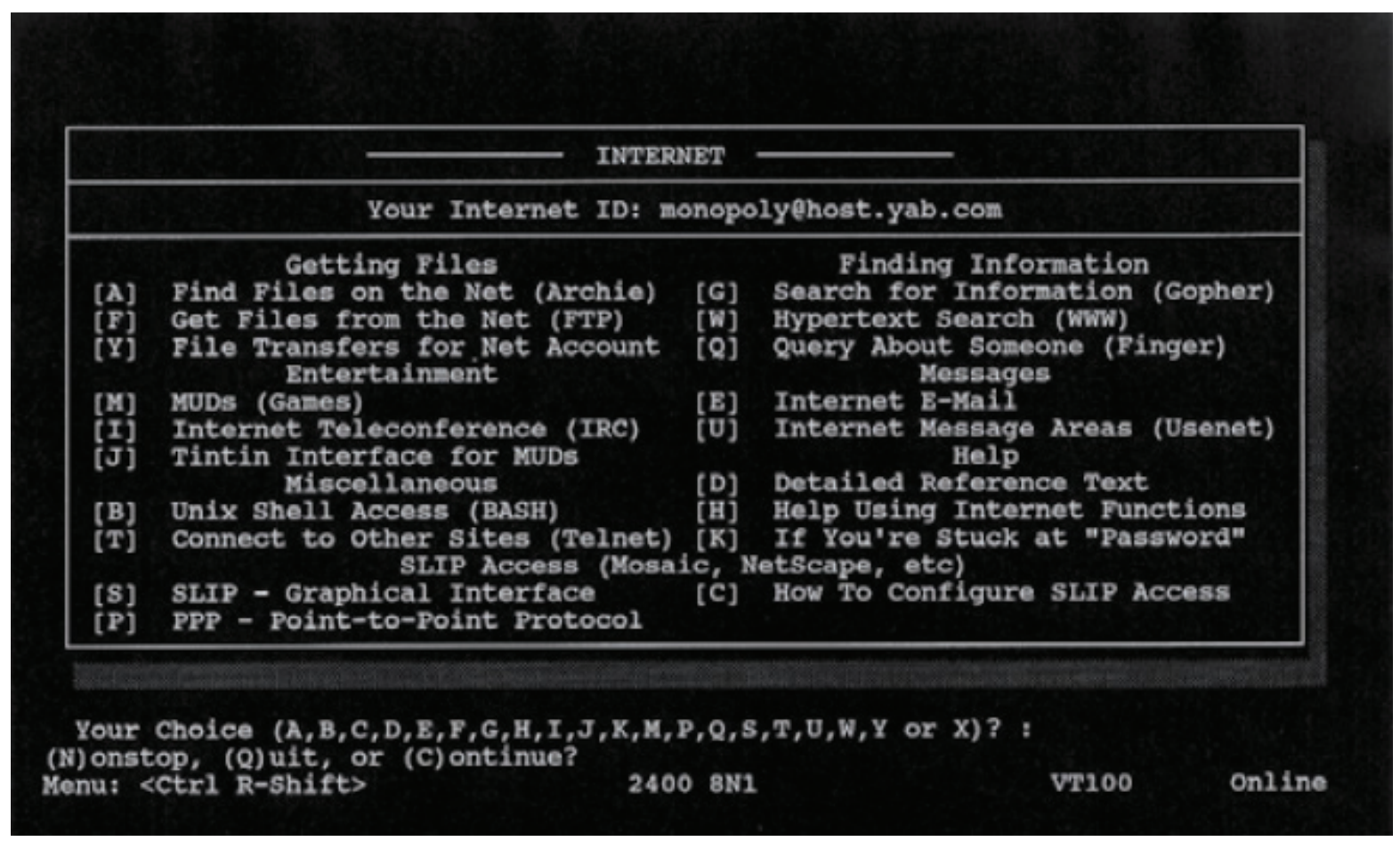

Figure 1. An early screenshot of internet

Source: Atkinson et al, 2010: 3

In order for companies to introduce new technologies, it is important that the change should be easy to happen. The new technology should be as much compatible with the old technologies as possible (Farrell, Saloner, 1992: 9). During the introduction of web solutions companies reported significant changes in their operations, the internet protocols (TCP/IP, HTML, etc.) and popular software are the bases of compatibility, whilst also providing opportunities for development. Websites can be viewed in the same way in today's browsers like in the early days, the e-mail as a communication solution unchanged for decades, only the displaying software and the hardware developed further.

\section{Internet as a general purpose technology}

The development of information technology improves information processing and dissemination. Atkinson et al (2010: 2) describes the importance of the internet causing historic breakthrough developments that are comparable to the introduction of cheap steel, the telephone, the internal combustion engine or 
the electricity. Such general purpose technologies (GPT) appeared historically about in each half centuries changing the economy drastically including the fact what the industry produces, how to organize and manage the output, where to produce geographically and what knowledge is required for it, furthermore it changes the infrastructure and also the laws. The GPT industries usually start in small, but then they spread rapidly throughout the economy. Meanwhile their costs drastically reduce, their performance increases, industries and products become an integral part of the processes, business models and causes innovation in organizations. (Atkinson et al, 2010: 2)

A good example for the GPTs is the internet and the online economy. Internet inthe beginning of the 2000s created new industries, such as online auctions and marketplaces (Porter, 2001: 5). Internet has some of the greatest impact on the existing businesses. The well-known model of Porter, the five-factor analysis can be used to analyse the internet on the impact of industry competition. There are positive and negative factors:

- Threat of substitute products:

$-(+)$ As the efficiency of the entire industry increases, the market size increases as well.

- (-) The internet may cause other alternative products.

- Entry barriers:

- (-) Some barriers to entry are reduced, as the number of sales personnel, sales channels or access to physical things - all those things that the internet technology eliminates.

- (-) Internet applications can be copied easily so it is hard to keep out new entrants.

- (-) New entrants flood the market.

- Bargaining power of customers:

$-(+)$ Eliminate the strong, traditional sales channels and improve the customers' bargaining power in these channels.

- (-) Improves the end-user bargaining position.

- (-) Standardization decreases the cost of switching.

- Bargaining power of suppliers:

- (+ / -) Companiescan reduce the bargaining power of suppliers by using the internet as supply channel, but on the other side, the suppliers will have access to more potential buyers as well.

- (-) The suppliers can easily access the buyers through online channels without the end-user commercial corporations.

- (-) Online markets ensure equal access for all companies to suppliers, helps to obtain uniform products, which lead to a reduction of differentiation.

- The intensity of competition:

- (-) The difference between the products of competitors reduces because it becomes more difficult to differentiate them from each other.

- (-) The competition is increasingly becoming a competition of price.

- (-) The geographic market becomes larger by increasing the number of competitors.

- (-) Decrease the proportion of variable costs relative to fixed costs, increasing the pressure for price reductions (Porter, 2001: 6). 


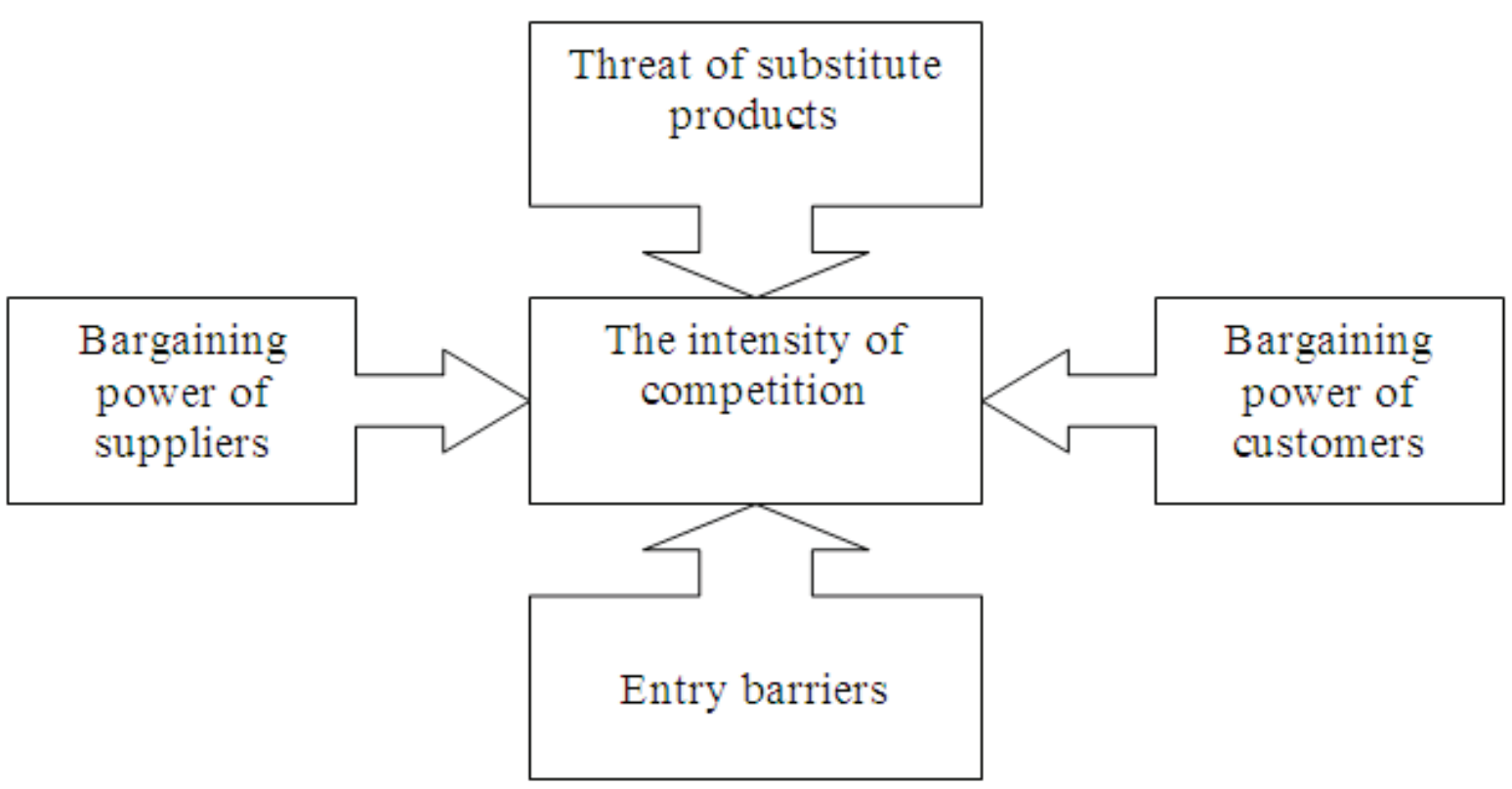

Figure 2. Porter's five forces model framework

Source: Porter, 1979: 6

\section{The online companies}

The online economy and the IT economy are interconnected, but the two are not identical. The online companies can be considered as a group of IT companies. While Amazon is a typical online company, primarily in hardware manufacturer Apple is said to be more like a traditional IT company. Hereinafter online companies are distinguished by the following:

- Mainly providing online products, services, contents or is an online intermediary company.

- A company that is functionally inseparable from the internet, for example having internet the main distribution channel.

The online economy rate can only be estimated, since many are not or hardly measurable. For example, it can not be that fast and simple online search will add to the economic indicators.

The online solutions allow companies to use the "long tail" phenomenon. The demand of typical traditional businessis limited, causing that rare, little-demanded products are hard to sell. While a typical bookstore has somewhere between 40000 to 100000 books, at Amazon there are 2.3 million books to choose from. The Posters.com offers 3500 various posters, at Ties.com customers can choose from 2500 different ties. In the Netflix online DVD rental service 65000 DVDs can be found, compared to a traditional movie rental shop's inventory of about $3000.40 \%$ of the income of Rhapsody online music service is derived from music not available in traditional stores offer (Atkinson, McKay, 2007: 45).

Using the internet a larger market can be accessed than using traditional distribution channels. In case of traditional companies the market can be defined as the population of the accessible geographical area. Even for firms operating in big cities the market is not as huge as the online potential market. For example, a shop in Budapest has a potential customer base of about 2 million people, while an online Hungarian store has 
about 4 million potential customers, because that many people use internet in Hungary nowadays. Regarding the special features it is the same concept. Online education and online health care supporting solutions are increasing. These services become economically available to the rural communities as well.

Whatever the product is, the online solutions help mass customization, which has the goal to customize mass-produced products within certain limits. The mass customization is to effectively distinguish the products for the customer by the greatest extent allowed by the supply chain (Chase, 2006). ByKaplan and Haenlein (2006: 176-177) this is a value-creating strategy based on the relationship of the company and the customer to manufacture and assemble products to create personalized mass-produced products on the same price levels as not customized products (Schmuck, 2012: 51). The online solutions improves the company and the consumer relationship, making it easier to assess needs and reduce changeover times and costs. This method is used for example by Lands End asking for exact sizes for our clothes ordered, providing a completely personalized outfit. Nike shoes can also be individualized, Quantum Cycles are producing custom-tailored manufactured bicycles. (Atkinson, McKay, 2007: 46) This method can be easily extended to services, for example the Hungarian Smart card holders get personalized offers from the Smart card operating companies (Shell, McDonald's, etc).

In the online economy financial markets are also affected. Sharetrading through online platforms largely shifted from the traditional broker trading to online trading methods. In Japan this feature became a huge commercial success. In 1999 there were only 300000 online broker accounts, but in 2006 this number reached 7.9 million, giving one quarter of the total shares trade in the country (Fackler, 2006: 1).

Public sector can use online services as well. Online public services offering services that are provided at a low cost can be made online. Municipalities usually provide such services: there is typically an online library of frequently asked questions for online office administration. These organizations can not be said to be operating online, they are only active in the online helping tools (Schmuck, 2011: 230).

Companies in the information technology contribute directly to economic performance, some statistics show that the $2 \%$ of the GDP of USA can be originated from these companies (Deighton, Quelch, 2009: 4). Although various estimates give different results, a search reveals that even in the middle of the $2000 \mathrm{~s}$ electronic commerce resulted in savings of $\$ 1.25$ billion for the global economy, which was about a whole 4.9 billion dollars. This is roughly a $25 \%$ savings compared to using traditional commerce (Dess, Lumpkin, 2004: 161). A survey in Great Britain shows that the use of e-procurement and e-sales combined causes improvement in productivity (Criscuolo, Waldron, 2003: 55). Although the values differ, there is a clear trend that using electronic commerce reduces costs. This also causes changes in consumer behaviour. Nowadays only $25 \%$ of the car vouchers, $30 \%$ of hotel nights and $50 \%$ of airline tickets are sold through traditional travel agencies (Atkinson et al, 2010: 44).

\section{Nationality of online companies}

We have seen that online companies are very important in today's economy. We have the presumption that online companies can be identified by online websites and they can be judged by the number of visitors. It is interesting to look into deeper where these websites operate. Many of the online companies are global, but each of them has its country of origin, where it is based. Before the analysis two hypothesis are set:

1. Countries with higher GDP has more websites.

2. Countries with higher population has more websites.

The research was done using the Alexa Top 500 database (Alexa, 2012). It is an online database of global websites. Alexa takes a sample of the visitors of websites by using a browser plugin. Based on this statistical data it provides a list of websites arranged by the number of visitors. The top 500 list of this global database can be accessed free at www.alexa.com. This is one of the most comprehensive database of websites worldwide. The research was done on the $1^{\text {st }}$ August 2012 state of this Alexa Top 500 list.

Each website was analysed one by one to determine its country of origin. There were a lot of duplicated websites in the database which were excluded (for example Google has different top-level-domain names 
for different countries). The websites were analysed deeply checking the operating company origin if possible, otherwise analysing the ownership of the domain name. This is not the same as the top-level-domain name. Besides some law restrictions in many countries any company can get any domain name with local top-level-domain name ending (for example .hu for Hungary). After excluding the duplications 419 websites remained. In nine cases it was not possible to check its origin due to technical or privacy problems. In 410 cases the county of origin could be determined. 48 different countries could be identified. Most of the websites are originated in the USA (182) and China (70). Table 1 shows the results by countries including GDP and the population data of the countries which are needed to analyse the hypothesis. The source of this data was mostly from the World Bank (2013), but in some cases data was missing at World Bank. In these cases it was needed to look for other sources.

Two correlation analysis were done on the data sheet. First, the correlation between the GDP of the country and the corresponding number of websites was analysed. It gave 0.928 which shows a tight connection between the GDP of the country and the number of websites in that country. Secondly the connection between the population and the number of websites was analysed. The result is 0.390 which is a weak correlation. Based on these values we can accept hypotheses 1 and reject hypotheses 2 . Countries with higher GDP has more websites.

There are limitations of the research. The less visited 'long tail' of websites were not included, only the biggest ones. There may be other online companies without websites with many visitors. These factors were excluded in the research, so the results can be accepted with these limitations only.

Table 1. Origin of websites in the Alexa 500 database including GDP and population

\begin{tabular}{|c|c|c|c|}
\hline & Websites & GDP (US\$, 2011) & Population (2011) \\
\hline Australia & 2 & 1379382221955 & 22620600 \\
\hline Bahamas & 1 & 7787514000 & 347176 \\
\hline Belgium & 1 & 513661111111 & 11008000 \\
\hline Brasilia & 6 & 2476652189880 & 196655014 \\
\hline British Virgin Islands & 1 & 853000000 & 31912 \\
\hline Bulgaria & 1 & 53514380731 & 7476000 \\
\hline Canada & 7 & 1736050505051 & 34482779 \\
\hline Cayman Islands & 0 & 3080000000 & 56729 \\
\hline China & 70 & 7318499269769 & 1344130000 \\
\hline Costa Rica & 1 & 40869768515 & 4726575 \\
\hline Cyprus & 4 & 24689602446 & 1116564 \\
\hline Czech Republic & 2 & 217026553672 & 10546000 \\
\hline Egypt & 1 & 229530568260 & 82536770 \\
\hline Estonia & 1 & 22154722222 & 1340000 \\
\hline France & 9 & 2773032125000 & 65436552 \\
\hline Germany & 15 & 3600833333333 & 81726000 \\
\hline Gibraltar & 1 & 1106000000 & 29111 \\
\hline Hong Kong & 4 & 248611896197 & 7071600 \\
\hline Hungary & 1 & 140029344474 & 9971000 \\
\hline India & 9 & 1847976748681 & 1241491960 \\
\hline Indonesia & 2 & 846832282925 & 242325638 \\
\hline Iran & 3 & 331014973186 & 74798599 \\
\hline Ireland & 2 & 217274951267 & 4487000 \\
\hline Israel & 4 & 242928731135 & 7765700 \\
\hline Italy & 6 & 2193971063086 & 60770000 \\
\hline Japan & 11 & 5867154491918 & 127817277 \\
\hline Luxemburg & 1 & 59200833333 & 517000 \\
\hline Netherlands & 4 & 836073611111 & 16696000 \\
\hline Netherlands Antilles & 2 & 3810000000 & 175653 \\
\hline Norway & 1 & 485803392857 & 4952000 \\
\hline
\end{tabular}




\begin{tabular}{|l|l|l|l|}
\hline & \multicolumn{1}{|c|}{ Websites } & \multicolumn{1}{|c|}{ GDP (US\$, 2011) } & \multicolumn{1}{|c|}{ Population (2011) } \\
\hline Philippines & 1 & 224753579833 & 94852030 \\
\hline Poland & 5 & 514496456773 & 38216000 \\
\hline Portugal & 2 & 237373611111 & 10637000 \\
\hline Romania & 1 & 179793512340 & 21390000 \\
\hline Russia & 10 & 1857769676144 & 141930000 \\
\hline Serbia & 1 & 45819561019 & 7261000 \\
\hline Seychelles & 4 & 1007186292 & 86000 \\
\hline South Africa & 1 & 408236752340 & 50586757 \\
\hline South Korea & 2 & 1116247397319 & 49779000 \\
\hline Spain & 4 & 1476881944444 & 46235000 \\
\hline Sweden & 2 & 539681664099 & 9453000 \\
\hline Switzerland & 1 & 659307920845 & 7907000 \\
\hline Turkey & 2 & 774983417981 & 73639596 \\
\hline United Arab Emirates & 1 & 360245074960 & 7890924 \\
\hline United Kingdom & 12 & 2445408064516 & 62641000 \\
\hline Uruguay & 1 & 46709797684 & 3368595 \\
\hline USA & 182 & 14991300000000 & 311591917 \\
\hline Vietnam & 1 & 123600141396 & 87840000 \\
\hline
\end{tabular}

Source: World Bank (2013/1) and World Bank (2013/2); excluding: British Virgin Islands: GDP 2004, Population 2013 (Est.), source: Geoba (2013); Gibraltar: GDP 2006, population 2013, source: CIA (2013); Netherlands Antilles: GDP 2008, source: United Nations (2009: 139); Iran: GDP 2009, source: World Bank (2013/1); Cayman Islands: GDP 2009, source: Trading Economics (2013)

\section{Conclusions}

After showing the importance of the global online economy a corresponding analysis was done. The paper looked for the answer if the number of websites originated from a country depends on the GDP or the population of that country - or they does not correlate at all. Based on this two hypothesis were formulated. After analysing the sample of the Alexa Top 500 database, one of the two hypothesis was accepted which states that the number of websites in a country correlates with the GDP of that country. However, a weak connection was also found between the population and the number of websites. Based on the research it can be stated that the online economy is heavily dominated by the USA and China.

The results show that the online economy is very much connected to the 'offline' traditional economy. Where the economy is stronger, the online economy develops similarly. This happens even if the online economy is considered an economy of new ideas and entrepreneurs creating huge venture enterprises from low-cost 'garages'. Finding the causes is not the topic of this paper, it could be a topic of a future research. The results show a huge disadvantage of less developed countries on their way to develop their online economy. As the correlation is very strong $(0,928)$ between GDP and the number of websites of a country it can be stated the development of the online economy of a country is mainly based on the 'traditional' economy of that country, the population does not really matter.

\section{References}

Alexa. (2012). Alexa Top 500. Website: http://www.alexa.com, accessed 1 ${ }^{\text {st }}$ August 2012.

Atkinson, R. D., McKay, A. S. (2007). Digital Prosperity. Understanding the Economic Benefits of the Information Technology Revolution. The Information Technology \& Innovation Foundation (ITIF).

Atkinson, R. D., Ezell, S. J., Andes, S. M., Castro, D. D., Bennett, R. (2010). The Internet Economy 25 Years after .com. Transforming Commerce \& Life. The Information Technology \& Innovation Foundation.

Chase, R. B., Jacobs, F. Rt, Aquilano, s. J. (2006). Operations Management for Competitive Advantage. 11th Edition. New York: McGraw-Hill/Irwin. 
CIA. (2013). The World Factbook: Gibraltar. Available at: https://www.cia.gov/library/publications/the-world-factbook/ geos/gi.html [accessed February 2013].

Criscuolo, C., Waldron, N. (2003). E-commerce and Productivity. Economic Trends, 600, November, p. 52-57. U.K. Office of National Statistics.

Deighton, J., Quelch, J. (2009). Economic Value of the Advertising-Supported Internet Ecosystem. Hamilton Consulting. Website: http://www.iab.net/media/file/Economic-Value-Report.pdf

Dess, G. G., Lumpkin, G. T. (2004). E-Business Strategies and Internet Business Models: How the Internet Adds Valus. Organizational Dynamics, May, Vol. 33, Issue 2.

Fackler, M. (2006). In Japan, Day-Trading Like It's 1999. New York Times. Website: http://www.nytimes.com/2006/02/19/ business/yourmoney/19day.html?_r=1.

Farrell, J., Saloner, G. (1992). Converters, Compatibility, and the Control of Interfaces. Journal of Industrial Economics, Vol. 40 (1), p. 9-35.

Geoba. (2013). The World: Population (2013) - Top 100+. Website: http://www.geoba.se/population. php? $\mathrm{pc}=$ world\&type $=028 \&$ page $=3$ [accessed $22^{\text {nd }}$ May 2013].

Internet World Stats. (2012). Internet Usage Statistics for the Americas. Miniwatts Marketing Group. Website: www. internetworldstats.com

Kaplan, A. M., Haenlein, M. (2006). Toward a Parsimonious Definition of Traditional and Electronic Mass Customization. Journal of Product Innovation Management, Vol. 23(2), p. 168-182.

Porter, M. (1979). How Competitive Forces Shape Strategy. Harvard Business Review, April-May.

Porter, M. (2001). Strategy and the Internet. Harvard Business Review, March.

Schmuck, R. (2011). Online Services of Municipal Websites. Human Resources - The Main Factor of Regional Development, Region Formation and Development Studies. Journal of Sciences, No. 5, p. 228-235. Klaipėda.

Schmuck, R. (2012). A sikeresvállalatkulcsa: stratégiák a termelésmenedzsmentben. E-conom, Nyugat-Magyarországi Egyetem, Vol. 1(1).

Trading Economics. (2013). Cayman Islands GDP. Website: http://www.tradingeconomics.com/cayman-islands/gdp [accessed February 2013].

United Nations. (2009). World Statistics Pocketbook. United Nations, Economic \& Social Affairs, USA.

World Bank. (2013/1). GDP (current US\$). Website: http://data.worldbank.org/indicator/NY.GDP.MKTP.CD [accessed February 2013].

World Bank. (2013/2). Population, Total. Website: http://data.worldbank.org/indicator/SP.POP.TOTL [accessed February 2013].

\section{VEIKSNIAI，VEIKIANTYS INTERNETINĘ EKONOMIKA SKIRTINGUOSE REGIONUOSE}

\section{Roland Schmuck}

Pecs universitetas (Vengrija)

\section{Santrauka}

Internetinė ekonomika globaliame pasaulyje atlieka svarbų vaidmeni. Internetas keičia bendrovių veiklos būdą, kartu keičia ir pačias rinkas. Internetinė ekonomika daro didelę itaką kasdieniam žmonių gyvenimui, privačioms bendrovèms ir viešosioms įstaigoms. Šio straipsnio tikslas - išanalizuoti globalią internetinę ekonomika, atsižvelgiant $\mathfrak{i}$ kilmès šali, siekiant nustatyti, kurios šalys internete dominuoja. Išanalizavus mokslinę literatūrą tiriamuoju klausimu, naudota Alexa Top 500 duomenų bazè, siekiant nustatyti labiausiai lankomus pasaulyje interneto puslapius. Analizè parodè, kad internetinejje ekonomikoje dominuoja JAV ir Kinija. Koreliacijų analizė patvirtino, kad šalies BVP koreliuoja su tinklalapių skaičiumi toje šalyje. Tai reiškia, kad labiau išsivysčiusiu šalių internetine ekonomika taip pat labiau išvystyta, yra daugiau tinklalapių.

PAGRINDINIAI ŽODŽIAI: globalizacija, internetine ekonomika, tinklalapis. 